\title{
Examination of UNECE Recommendations to Enhance Energy Efficiency in Buildings using DEMATEL
}

\author{
S.S.Qarnain, S. Muthuvel, S. Bathrinath
}

\begin{abstract}
Achieving Energy efficiency in Buildings is one of the national Key Performance Indicators in many countries. Because Major part of the generated energy is consumed by buildings, it is evident that achieving energy efficiency in buildings compliments in conservation of energy and its resources along with attaining sustainability. This research work is analysis of such building energy efficiency recommendations for Enhancing energy efficiency in buildings. The recommendations discussed in this paper were proposed by United Nations Economic commission for Europe (UNECE) for UNECE region consisting of 56 member countries. This paper analyses the UNECE recommendations, their cause and effects through Decision making trial and evaluation laboratory (DEMATEL) methodology. The results showed that among all the recommendations, the two that had greater potential in achieving the goal of energy efficiency in buildings are a) National and local authorities' coordination for continuous development and implementation of building codes and b) Energy policy and legislation. The paper also discusses managerial applications of this research work and provides insight into the recommendations.
\end{abstract}

Keywords: Buildings, DEMATEL, Energy efficiency.

\section{INTRODUCTION}

Improvement in building energy efficiency is one among the most affordable and cost-effective ways for satisfying the growing energy demand in many countries. Because, it adds to energy security, a better environment, better life style, and economic wellbeing of a society. Energy is a fundamental need of every individual because it is used in essential services of individuals daily routine like cooking, lighting, heating, cooling, mobility and operation of household appliances (UNECE Report 2017) and most of these daily routines happens to be inside buildings that we live in. Buildings are important part of the society and integral to all economic sectors of a country such as industries and manufacturing sector, Universities and schools, Tourism and hospitality and many more. Additionally, buildings hold the highest potential in cost effective improvements in reducing carbon emission and achieving energy efficiency [1] thereby making buildings deserving area to attempt for energy efficient use.

Revised Manuscript Received on December 05, 2019.

* Correspondence Author

S.S.Qarnain, Department of mechancical engineering, Kalasalingam Academy of research and education, Krishnankoil-626126, India. Email: drqarnain@gmail.com

S.Muthuvel, Department of mechancical engineering, Kalasalingam Academy of research and education, Krishnankoil-626126, India. Email: bathri@gmail.com

S.Bathrinath*, Department of mechancical engineering, Kalasalingam Academy of research and education, Krishnankoil-626126, India. Email: ssaravanasankar@klu.ac.in
United nation economic commission for Europe (UNECE) is a European union member organization consist of 56 Countries. The energy intensity of buildings in this region is very high when compare to global context. Because of global pressure to mitigate climate change in vast UNECE region and its potential to contribute in reduced carbon emissions leading to impact on climate change, Support policies for energy efficiency received increased attention in recent years. (UNECE Report 2017a). This motivated us to analyze the energy efficiency recommendations of the UNECE report and form a basis of research case for this Research work.

\section{RELEVANT LITERATURE}

Numerous reports have been published necessitating the need for energy efficiency in building sector in UNECE Region, The UNECE renewable energy reports 2017 reports that the Energy use intensity (EUI) of buildings is high in spite of reduction driven by climatic conditions, structural economic factors and by inefficiencies in energy conversions. And most energy efficiency policies and projects target building sector to reduce energy consumption (UNECE Report 2017a).

International energy agency reports that the energy efficiency market highlights that the state of global energy efficiency has already evolved to a state where its largest promoter to energy services is the "first fuel" in IEA member countries and in international market it is placed at over USD 130 billion (UNECE, Best policy Practices Report 2017).

Buildings sector. Apart from saving energy along with monetary benefits also provides numerous non-financial benefits (NEB's)that make energy efficiency projects more lucrative to adopt. Some of the NEB's are increased asset value in real estate, increased Productivity for businesses, improved comfort, health and safety of the occupants and reduced system Maintenance and operational costs [1].

The ninth international forum for sustainable energy development by United nations that met on 15 November 2018 with over more than 60 participant countries focused on emphasizing the policies and measures taken in the UNECE region to provide a lenient framework on reducing the existing legislative policy, economic and financial barriers to increase investment and encourage flow of finance in order to promote energy efficiency(UNECE Report 2018). This emphasizes wide significance attained globally to promote energy efficiency in buildings and particularly in the UNECE region. 
The European parliament in Dec 2018 with the Council of the European Union adopted revised Energy Efficiency Directive that set the energy efficiency target to be at least $32.5 \%$ by 2030 (European Commission 2019). Setting the stage for starting new projects to fulfil this goal of 32.55 reduction by all European Union member countries.

One of the most highly developed areas for Energy efficiency in buildings is of governmental regulatory policies .Most of the Projects in All UNECE countries are ongoing supported by financing from international donors such as the German Agency for International Cooperation (GIZ), the World Bank, , the Swedish Development Agency and the US Agency for International Development (USAID), the United Nations Development Program (UNDP), With regard to energy efficiency services(UNECE Report 2017a) [2].This emphasizes the energy efficiency in buildings is one of the driving force behind financial investment by global financial investors in UN Region.

\section{METHODOLOGY}

DEMATEL method is used to analyze the cause and effect relationship among the factors. The analysis of factors results in a structural model that is differentiated into Cause and effect groups [3]. Thus providing insight on interdependencies of factors and their effect on the entire system. DEMATEL was first reported by Battelle memorial institute through Geneva research Centre [8], It helps to visualize problems on graph as it is developed on the basis of graph theory [4], DEMATEL method provides good understanding of intertwined problems to stake holders and helps decision makers to arrive at the correct decision for specific problems [5] The steps involved in DEMATEL are :(1) Formation of Direct relation matrix through expert inputs

(2) Compute Average Matrix for Direct Relation Matrix

(3) Normalization of the direct relation Matrix

(4) Obtain Total Relation Matrix

(5) Calculate the Sum of Rows and Columns of Total Relation Matrix

6) Constitute the Cause and effect diagram for analysis.

[6]

Step 1. Formation of direct Relation Matrix: - By utilizing the inputs from the subject experts with the help of a scale that ranges from 0 to 4 as shown in the table 1 [7]. An initial direct relation matrix is formed by using the pairwise comparison of the criteria in which $T_{i j}$ is the degree to which the factor $i$ affects the factor $j$, which is given by the equation

$$
T=\left[t_{\mathrm{ij}}\right]_{\mathrm{n} X \mathrm{n}}
$$

$$
A=\left[\begin{array}{cccccc}
1 & a_{12} & a_{13} & \ldots & a_{1(n-1)} & a_{1 n} \\
a_{21} & 1 & a_{23} & \ldots & a_{2(n-1)} & a_{2 n} \\
\ldots & \ldots & \ldots & \ldots & \ldots & \ldots \\
\ldots & \ldots & \ldots & \ldots & \ldots & \ldots \\
a_{(n-1) 1} & a_{(n-1) 2} & a_{(n-1) 3} & \ldots & 1 & a_{(n-1) 1} \\
a_{n 1} & a_{n 2} & a_{n 3} & \ldots & a_{n(n-1)} & 1
\end{array}\right]
$$

Table- I. Influence scale

\begin{tabular}{|c|c|}
\hline Scale & Influence \\
\hline 0 & No Influence \\
\hline 1 & Very low influence \\
\hline 2 & Low influence \\
\hline 3 & High Influence \\
\hline 4 & Very High Influence \\
\hline
\end{tabular}

Step 2: -The n number of expert opinions are averaged to get the average direct relation matrix $\mathrm{A}$

Step 3: - by applying equation 2 The normalized direct relation matrix, $\mathrm{N}$ can be obtained.

$$
\mathrm{N}=\mathrm{K} \times \mathrm{A}
$$

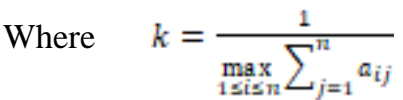

Step 4: - Obtain the total relation Matrix from matrix $N$ given by equation 2 , I in the total relation matrix in equation 4 is the identity matrix.

i.e. $\quad T=X(I-X)^{-1}$

Step 5:- From the total relation matrix, Calculate the sum of vector D i.e. sum of horizontal rows and Vector $\mathrm{R}$ sum of vertical columns, A cause and effect diagram is obtained by Plotting D+R and D-R, The resultant Vector D+R is the called as "Prominence" and vector $\mathrm{D}-\mathrm{R}$ i.e. cause group is named as "Relation". If D-R is negative, then it is grouped into effect Group otherwise it is grouped into Cause group $(R \mathrm{j}$ Lin, 2013))

The final matrices are represented by equation 5, 6 and 7

$$
\begin{aligned}
& T=\left[t_{i j}\right]_{n \times n}, i, j=1,2, \ldots, n \\
& D=\left[\sum_{i=1}^{n} t_{i j}\right]_{\mathbb{1 \times n}}=\left[t_{j}\right]_{n \times 1} \\
& R=\left[\sum_{j=1}^{n} t_{i j}\right]_{\mathbb{1 \times n}}=\left[t_{j}\right]_{n \times 1}
\end{aligned}
$$

\section{APPLICATION OF THE PROPOSED MODEL TO THE CASE ILLUSTRATION}

The ten recommendations made in "Mapping of Existing Technologies to Enhance Energy Efficiency in Buildings in the UNECE Region" produced by Joint Task force on energy efficiency standards in Buildings was taken into consideration for this research work. This paper analyses the ten recommendations there cause and effects in achieving energy efficiency in buildings. The ten recommendations are provided in Table 2 .

Table- II. Reccomendations for Achieving Energy efficiency in Buildings in UNECE Region

\begin{tabular}{|c|c|}
\hline R1. & Policy and legislation \\
\hline R2. & Public and private sector partnership \\
\hline R3. & Align energy efficiency with National Contributors \\
\hline R4. & Awareness on Benefits of Energy Efficiency Certifications \\
\hline R5. & Technological adoption through Effective Awareness camping \\
\hline R6. & Building retrofit \\
\hline
\end{tabular}




\begin{tabular}{|c|c|}
\hline R7. & $\begin{array}{c}\text { National and local authorities' coordination for continuous } \\
\text { development and implementation of building codes }\end{array}$ \\
\hline R8. & Financial investment by Government \\
\hline R9. & Capacity building for Promotion of retrofits in buildings \\
\hline R10 & Enhanced use of Building Energy Certificates \\
\hline
\end{tabular}

Step 1: - Twenty Energy experts from various domains of energy sector provided input by using table 1- influence scale, for the ten recommendations in Table 2. The questionnaire provided to Experts is given in Appendix A of this paper. Out of these twenty subject experts five were Building Energy Managers over 10 years of experience, six were Building Energy Design Consultants over seven years of designing experience, three were Academic professors over 15 years of Experience, five were from on site Design execution and contractors over 12 years of experience, and four Government Energy policy makers in the department of building energy efficiency. The entire Energy expert's team had a minimum educational qualification of Graduation and maximum qualification was a doctoral degree in energy related field

Step 2: - The direct relation matrix that was obtained in the as a resultant of step is Averaged for all the values in Table 3. And the sum and rows and columns are computed to get a value of 0.042 by using equation 3 .

Step 3: - Table 4 i.e. The normalized matrix is obtained by applying equation 2 and using Table 3 .

Step 4: - The total relation matrix by using equation 4 is obtained presented in Table 5. And the sum of rows and columns is computed to obtain Vector D and Vector R by using equation 5, 6 and 7. The Vector D, Vector R, D+R and $\mathrm{D}-\mathrm{R}$ is presented in table 6 .

\section{RESULT AND DISCUSSIONS}

From Table 8 the priorities of the recommendation starting from highest to lowest are $\mathrm{R} 7>\mathrm{R} 1>\mathrm{R} 9>\mathrm{R} 10>\mathrm{R} 2>\mathrm{R} 8>$ $\mathrm{R} 3>\mathrm{R} 6>\mathrm{R} 5>\mathrm{R} 4$, the ranking is based on the $\mathrm{D}+\mathrm{R}$ i.e. prominence vector, The Cause and effect diagram shows 4 recommendations in the effect group and 6 recommendations grouped under cause group.

Effect group Recommendations are easily influenced by cause group elements and has the potential to change the entire system [8]. The highest rank among the recommendations is R7- National and local authorities' coordination for continuous development and implementation of building codes

with a prominence score of 13.45 and R1-i. e policy and legislation with a Prominence score of 12.87 , both are effect group recommendations. Implying that these are the two most important Recommendations to be taken into consideration to obtain the goal of building energy efficiency. The Last rank is of R4- Awareness on Benefits of Energy Efficiency Certifications That is bear less impact on the energy efficiency goal.

Cause group factors are essential factors that centers all other factors around them [9] Figure 1, table 6 and 7 shows the highest cause group elements as R2 and R10 that has high potential to cause a change to other group elements.From Figure -1, Among the Causal group the top two recommendations are R2-Public Private partnership and R10-Enhanced use of Building Energy Certificates. Because the end users of buildings are general public therefore the energy efficiency initiatives has to get started by the them paving the way for creating a demand for energy efficiency, this demand can be satisfied by government through public private partnership initiatives.

One more initiative for energy efficiency is the achieving of building energy certificates i.e recommendation R10, these certificates are awarded by a competent authority for a performing building in the field of energy efficiency, These certificates acts as a motivating force to encourage building owners to attempt for building energy efficiency program in their premises.

The third position in Cause group is attained by R5-Technological adoption through effective awareness campaigns. It is through awareness and education that the stake holders of energy efficiency gets informed, it is necessary that to achieve energy efficiency one has to be well informed and aware of latest technological advancements in the field. Therefore recommendation R5 has great potential in making into cause group to achieve energy efficiency. Recommendation R6 -Retrofit is also in the cause group and has good potential to achieve energy efficiency because retrofit is a opportunity for building owners and stakeholders to install and refurbish the old inefficient energy systems from the buildings. This retrofit can be either at the preventive maintenance time or at refurbishing time, either ways retrofit has great opportunity to add value in energy efficiency.

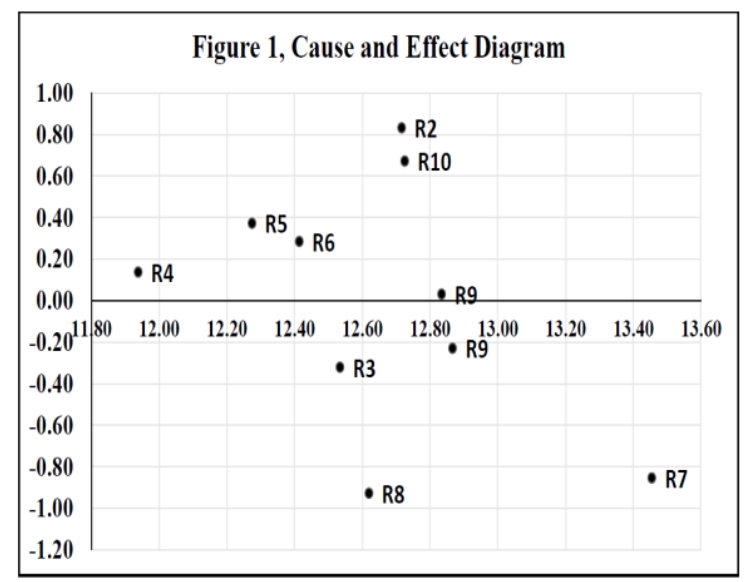

Fig. 1. Cause and Effect diagram

\section{CONCLUSION AND FUTURE SCOPE}

From the results obtained in Table 8 and figure 1, we can conclude that the most important recommendations that should be given priority for achieving energy efficiency in buildings are R7and R1, i.e R7- National and local authorities coordination for continuous development and implementation of building codes and R1-Policy and legislation.

As because the buildings tend to lose efficiency as they gets older with time and it will be subjected to a number of changes throughout its life cycle, therefore in order to achive energy efficiency in building as per reccomendation R7, these changes has to be incorporated in building codes through reassesment and over continious improvement cycle. To align the building construction industry and orient them towards achiveing higher energy efficiency, Energy Policy and legislation has to be implemented. The result 
also shows that R2-Public and Private sector partnership is also one of the reccomendation that has the potential to effect other reccomendations in a larger way because of its highest Casual score.

The results provided in this research work can be beneficial to decision makers and policy makers in the UNECE region .Many building energy efficiency projects could benefit from the cause and effect diagram while applying framework on financial investment, Public private partnetship, Building energy Efficiency Code development, formation of legislation etc.

This research work has analysed Recommendations for UNECE Region only, furtherscope of this research could be a analysis of Reccomendation for building energy efficiency for different geographical area and a comparative conclusion could be drawn. Furthermore a Extended study of the Reccomendations could be done using ISM and PROMETHEE methodology to know the synergies and conflicts between each recommendations.

\section{REFERENCES}

1. M. Kranti, K. Dubey and N. Howarth, "Energy productivity analysis framework for buildings: a case study of GCC region," Energy, Vol. 167, 2019, 1251-1265.

2. S. Luthra, K. Govindan, R. K. Kharb and S. K. Mangla, "Evaluating the enablers in solar power developments in the current scenario using fuzzy DEMATEL: An Indian perspective," Renewable and Sustainable Energy Reviews, Vol. 63, 2016, 379-397.

3. A. Gabus and E. Fontela, "World problems, an invitation to further thought within the framework of DEMATEL," Battelle Geneva Research Centre, Geneva, Switzerland, 1972, 1-8

4. R. J. Lin, "Using fuzzy DEMATEL to evaluate the green supply chain management practices," Journal of Cleaner Production, Vol. 40 , 2013, 32-39.

5. J. Ren, A. Manzardo, S. Toniolo and A. Scipioni, "Sustainability of hydrogen supply chain. Part I: identification of critical criteria and cause-effect analysis for enhancing the sustainability using DEMATEL," International journal of hydrogen energy, Vol. 38(33), 2013, 14159-14171

6. K. Govindan and A. Chaudhuri, "Interrelationships of risks faced by third party logistics service providers: A DEMATEL based approach," Transportation Research Part E: Logistics and Transportation Review, Vol. 90, 2016, 177-195

7. S.Bathrinath, V. S. Charan, S. G. Ponnambalam and S. Saravanasankar, "Identification and Evaluation of Criteria of Agile Manufacturing Using DEMATEL: A Case from an Indian Metal Fabrication Industry," Journal of Modern Manufacturing Systems and Technology, Vol. 2(1), 2019, 61-74.

8. X. Xia, K. Govindan and Q. Zhu, "Analysing internal barriers for automotive parts remanufacturers in China using grey-DEMATEL approach," Journal of Cleaner Production, Vol. 87, 2015, 811-825.

9. R. K. A. Bhalaji, S. Bathrinath, S. G. Ponnambalam and S. Saravanasanka, "A Fuzzy Decision-Making Trial and Evaluation Laboratory approach to analyse risk factors related to environmental health and safety aspects in the healthcare industry," Sādhanā, Vol 44(3), 2019, 55

\section{AUTHORS PROFILE}

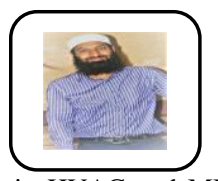

Syed Shuib ul Qarnain is a Chartered Engineer(CEng) from Engineering Council U.K and Chartered Building service engineer from CIBSE, London. He is LEED accredited professional (LEED AP) from United States Green Building Council (USGBC). He obtained M.Tech in HVAC and MBA in Project Management. Currently he is a Research Scholar in the Department of Mechanical Engineering, Kalasalingam Academy of Research and Education, Krishnankoil, Tamilnadu, India. His research involvement is in the field of conservation of energy in Buildings using MCMD methods.
Dr.S.Muthuvel is an Associate Professor in the Department of Mechanical Engineering, Kalasalingam Academy of Research and Education, Krishnankoil, Tamilnadu, India. His current area of research

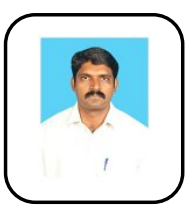
includes phase change materials and energy conservation. He has published a number of papers in journal of national/international repute and presented a number of papers in various conferences/symposia in India and abroad. He is presently guiding a number of master/doctoral research scholars.

Dr.S.Bathrinath is an Associate Professor in the Department of Mechanical Engineering, Kalasalingam Academy of

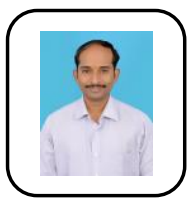
Research and Education, Krishnankoil, Tamilnadu, India His current area of research includes multi-criteria decision making, scheduling \& optimization, soft computing and Artificial intelligence. He has published a number of papers in journal of national/international repute and presented a number of papers in various conferences/symposia in India and abroad. He is presently guiding a number of master/doctoral research scholars.

\section{Appendix A: Questionnaire}

The following is the format of Survey questionnaire provided to experts for their input.

Name: -

Organization:

Position and qualification:

Energy Experience in years:

Email and telephone: -

We further declare that all the data of this survey and details will not be distributed or made public by any means, it will not be circulated on social networking sites neither be made available to your competitor or for any marketing purpose. This data will be used only for research purpose and solely intended to provide input for ongoing research work.

Table- A: Influence scale

\begin{tabular}{|c|c|}
\hline Linguistic Variable & Influence Score \\
\hline No influence & 0 \\
\hline Very Low Influence & 1 \\
\hline Low Influence & 2 \\
\hline High Influence & 3 \\
\hline Very High Influence & 4 \\
\hline
\end{tabular}

Kindly fill the boxes below (in Table A.1) with one of the influence score from Table $\mathrm{A}$, the requirements (R)are given in Table A.2

For example; - if R1 has a high influence on R4 then an influence score of 3 is inserted. 
Table A.1

\begin{tabular}{|l|l|l|l|l|l|l|l|l|l|l|}
\hline & R1 & R2 & R3 & R4 & R5 & R6 & R7 & R8 & R9 & R10 \\
\hline R1 & & & & & & & & & & \\
\hline R2 & & & & & & & & & & \\
\hline R3 & & & & & & & & & & \\
\hline R4 & & & & & & & & & & \\
\hline R5 & & & & & & & & & & \\
\hline R6 & & & & & & & & & & \\
\hline R7 & & & & & & & & & & \\
\hline R8 & & & & & & & & & & \\
\hline R9 & & & & & & & & & & \\
\hline R10 & & & & & & & & & & \\
\hline
\end{tabular}

The input from your Expertise and knowledge will help us bringing out a positive and fruitful research result that can be productive to community and society. Thank you for your precious time.

Table- II: Recommendations for Achieving Energy efficiency in Buildings in UNECE Region

\begin{tabular}{|c|c|}
\hline R1. & Policy and legislation \\
\hline $\mathrm{R} 2$. & Public and private sector partnership \\
\hline R3. & Align energy efficiency with National Contributors \\
\hline R4. & Awareness on Benefits of Energy Efficiency Certifications \\
\hline R5. & $\begin{array}{l}\text { Technological adoption through Effective Awareness } \\
\text { campaigns. }\end{array}$ \\
\hline R6. & Building retrofit \\
\hline R7. & $\begin{array}{l}\text { Reassessment of building codes and coordination of } \\
\text { authorities }\end{array}$ \\
\hline R8. & Financial investment by Government \\
\hline R9. & Capacity building for Promotion of retrofits in buildings \\
\hline R10 & Enhanced use of Building Energy Certificates \\
\hline
\end{tabular}

Table- III: Average Direct Relation Matrix

\begin{tabular}{|l|l|l|l|l|l|l|l|l|l|l|l|}
\hline & R1 & R2 & R3 & R4 & R5 & R6 & R7 & R8 & R9 & R10 & Sum \\
\hline R1 & 0 & 1.95 & 2.1 & 2.5 & 2.05 & 3.05 & 2.15 & 2.05 & 2.2 & 2.5 & $\mathbf{2 0 . 5 5}$ \\
\hline R2 & 2 & 0 & 2 & 2.15 & 1.9 & 2.6 & 3.2 & 3 & 3 & 2.35 & $\mathbf{2 2 . 2 0}$ \\
\hline R3 & 2.55 & 1.8 & 0 & 2.2 & 2.1 & 2.45 & 1.85 & 2.45 & 2.5 & 1.95 & $\mathbf{1 9 . 8 5}$ \\
\hline R4 & 2.15 & 2.8 & 1.65 & 0 & 2.35 & 2.4 & 2.25 & 1.4 & 2.2 & 2.25 & $\mathbf{1 9 . 4 5}$ \\
\hline R5 & 2.9 & 2.25 & 3 & 1.7 & 0 & 1.4 & 2.15 & 3.15 & 2.1 & 2 & $\mathbf{2 0 . 6 5}$ \\
\hline R6 & 2 & 2.75 & 2.9 & 1.85 & 3 & 0 & 2 & 1.8 & 1.75 & 2.55 & $\mathbf{2 0 . 6 0}$ \\
\hline R7 & 3 & 2.3 & 2.05 & 2 & 1.95 & 1.6 & 0 & 3.3 & 2.25 & 2.1 & $\mathbf{2 0 . 5 5}$ \\
\hline R8 & 1.9 & 1.7 & 3 & 2.25 & 1.6 & 1.45 & 3 & 0 & 2 & 2.05 & $\mathbf{1 8 . 9 5}$ \\
\hline R9 & 2.65 & 1.8 & 1.8 & 2 & 2.05 & 2.1 & 3.75 & 3.1 & 0 & 1.8 & $\mathbf{2 1 . 0 5}$ \\
\hline R10 & 2.15 & 1.95 & 2.45 & 2.4 & 2.35 & 2.7 & 3.2 & 1.8 & 2.9 & 0 & $\mathbf{2 1 . 9 0}$ \\
\hline Sum & $\mathbf{2 1 . 3 0}$ & $\mathbf{1 9 . 3 0}$ & $\mathbf{2 0 . 9 5}$ & $\mathbf{1 9 . 0 5}$ & $\mathbf{1 9 . 3 5}$ & $\mathbf{1 9 . 7 5}$ & $\mathbf{2 3 . 5 5}$ & $\mathbf{2 2 . 0 5}$ & $\mathbf{2 0 . 9 0}$ & $\mathbf{1 9 . 5 5}$ & \\
\hline
\end{tabular}

Table- IV. Normalized matrix

\begin{tabular}{|c|c|c|c|c|c|c|c|c|c|c|}
\hline & $\mathrm{R} 1$ & $\mathrm{R} 2$ & R3 & R4 & R5 & R6 & R7 & R8 & R9 & $\mathrm{R} 10$ \\
\hline $\mathrm{R} 1$ & 0 & 0.082 & 0.088 & $\begin{array}{r}0.10 \\
5 \\
\end{array}$ & 0.086 & $\begin{array}{r}0.12 \\
8 \\
\end{array}$ & 0.09 & $\begin{array}{r}0.08 \\
6 \\
\end{array}$ & 0.092 & $\begin{array}{r}0.10 \\
5 \\
\end{array}$ \\
\hline $\mathrm{R} 2$ & 0.084 & 0 & 0.084 & 0.09 & 0.08 & $\begin{array}{r}0.10 \\
9 \\
\end{array}$ & $\begin{array}{r}0.13 \\
4 \\
\end{array}$ & $\begin{array}{r}0.12 \\
6 \\
\end{array}$ & 0.126 & $\begin{array}{r}0.09 \\
9 \\
\end{array}$ \\
\hline $\mathrm{R} 3$ & 0.107 & 0.076 & 0 & $\begin{array}{r}0.09 \\
2\end{array}$ & 0.088 & $\begin{array}{r}0.10 \\
3\end{array}$ & $\begin{array}{r}0.07 \\
8 \\
\end{array}$ & $\begin{array}{r}0.10 \\
3\end{array}$ & 0.105 & $\begin{array}{r}0.08 \\
2 \\
\end{array}$ \\
\hline $\mathrm{R} 4$ & 0.09 & 0.118 & 0.069 & 0 & 0.099 & $\begin{array}{r}0.10 \\
1\end{array}$ & $\begin{array}{r}0.09 \\
5\end{array}$ & $\begin{array}{r}0.05 \\
9\end{array}$ & 0.092 & $\begin{array}{r}0.09 \\
5 \\
\end{array}$ \\
\hline $\mathrm{R} 5$ & 0.122 & 0.095 & 0.126 & $\begin{array}{r}0.07 \\
1 \\
\end{array}$ & 0 & $\begin{array}{r}0.05 \\
9 \\
\end{array}$ & 0.09 & $\begin{array}{r}0.13 \\
2 \\
\end{array}$ & 0.088 & $\begin{array}{r}0.08 \\
4 \\
\end{array}$ \\
\hline R6 & 0.084 & 0.116 & 0.122 & $\begin{array}{r}0.07 \\
8\end{array}$ & 0.126 & 0 & $\begin{array}{r}0.08 \\
4\end{array}$ & $\begin{array}{r}0.07 \\
6\end{array}$ & & ${ }^{2}$ \\
\hline
\end{tabular}


Examination of UNECE Recommendations to Enhance Energy Efficiency in Buildings using DEMATEL

\begin{tabular}{|c|c|c|c|c|c|c|c|c|c|c|}
\hline R7 & 0.126 & 0.097 & 0.086 & $\begin{array}{r}0.08 \\
4\end{array}$ & 0.082 & $\begin{array}{r}0.06 \\
7\end{array}$ & 0 & $\begin{array}{r}0.13 \\
9\end{array}$ & 0.095 & $\begin{array}{r}0.08 \\
8\end{array}$ \\
\hline R8 & 0.08 & 0.071 & 0.126 & $\begin{array}{r}0.09 \\
5 \\
\end{array}$ & 0.067 & $\begin{array}{r}0.06 \\
1 \\
\end{array}$ & $\begin{array}{r}0.12 \\
6 \\
\end{array}$ & 0 & 0.084 & $\begin{array}{r}0.08 \\
6 \\
\end{array}$ \\
\hline R9 & 0.111 & 0.076 & 0.076 & $\begin{array}{r}0.08 \\
4 \\
\end{array}$ & 0.086 & $\begin{array}{r}0.08 \\
8 \\
\end{array}$ & $\begin{array}{r}0.15 \\
8 \\
\end{array}$ & 0.13 & 0 & $\begin{array}{r}0.07 \\
6 \\
\end{array}$ \\
\hline R10 & 0.09 & 0.082 & 0.103 & $\begin{array}{r}0.10 \\
1\end{array}$ & 0.099 & $\begin{array}{r}0.11 \\
3\end{array}$ & $\begin{array}{r}0.13 \\
4\end{array}$ & $\begin{array}{r}0.07 \\
6\end{array}$ & 0.122 & 0 \\
\hline
\end{tabular}

Table- V: Total relation matrix

\begin{tabular}{|l|l|l|l|l|l|l|l|l|l|l|l|}
\hline & R1 & R2 & R3 & R4 & R5 & R6 & R7 & R8 & R9 & R10 & \\
\hline R1 & 0.57 & 0.60 & 0.64 & 0.61 & 0.60 & 0.65 & 0.71 & 0.67 & 0.64 & 0.62 & $\mathbf{6 . 3 2}$ \\
\hline R2 & 0.69 & 0.56 & 0.68 & 0.64 & 0.63 & 0.67 & 0.79 & 0.75 & 0.71 & 0.66 & $\mathbf{6 . 7 7}$ \\
\hline R3 & 0.65 & 0.57 & 0.54 & 0.58 & 0.58 & 0.61 & 0.68 & 0.67 & 0.64 & 0.59 & $\mathbf{6 . 1 1}$ \\
\hline R4 & 0.63 & 0.60 & 0.60 & 0.49 & 0.59 & 0.60 & 0.69 & 0.62 & 0.62 & 0.59 & $\mathbf{6 . 0 4}$ \\
\hline R5 & 0.68 & 0.60 & 0.68 & 0.58 & 0.52 & 0.59 & 0.71 & 0.71 & 0.64 & 0.60 & $\mathbf{6 . 3 2}$ \\
\hline R6 & 0.65 & 0.63 & 0.68 & 0.59 & 0.64 & 0.53 & 0.71 & 0.67 & 0.63 & 0.63 & $\mathbf{6 . 3 5}$ \\
\hline R7 & 0.68 & 0.61 & 0.64 & 0.59 & 0.59 & 0.59 & 0.63 & 0.71 & 0.64 & 0.61 & $\mathbf{6 . 3 0}$ \\
\hline R8 & 0.61 & 0.55 & 0.63 & 0.56 & 0.54 & 0.55 & 0.69 & 0.55 & 0.60 & 0.57 & $\mathbf{5 . 8 5}$ \\
\hline R9 & 0.68 & 0.60 & 0.64 & 0.60 & 0.61 & 0.62 & 0.78 & 0.72 & 0.57 & 0.61 & $\mathbf{6 . 4 3}$ \\
\hline R10 & 0.69 & 0.63 & 0.69 & 0.64 & 0.64 & 0.66 & 0.78 & 0.70 & 0.70 & 0.56 & $\mathbf{6 . 7 0}$ \\
\hline & $\mathbf{6 . 5 5}$ & $\mathbf{5 . 9 4}$ & $\mathbf{6 . 4 3}$ & $\mathbf{5 . 9 0}$ & $\mathbf{5 . 9 5}$ & $\mathbf{6 . 0 6}$ & $\mathbf{7 . 1 5}$ & $\mathbf{6 . 7 7}$ & $\mathbf{6 . 4 0}$ & $\mathbf{6 . 0 3}$ & \\
\hline
\end{tabular}

Table- VI. Rank of the Recommendations

\begin{tabular}{|l|l|l|l|l|l|l|}
\hline & D & S & D+S & Rank & D-S & Group \\
\hline R1. & 6.32 & 6.55 & 12.87 & 2 & -0.23 & Effect \\
\hline R2. & 6.77 & 5.94 & 12.72 & 5 & 0.83 & Cause \\
\hline R3. & 6.11 & 6.43 & 12.53 & 7 & -0.32 & Effect \\
\hline R4. & 6.04 & 5.90 & 11.94 & 10 & 0.14 & Cause \\
\hline R5. & 6.32 & 5.95 & 12.27 & 9 & 0.37 & Cause \\
\hline R6. & 6.35 & 6.06 & 12.41 & 8 & 0.29 & Cause \\
\hline R7. & 6.30 & 7.15 & 13.45 & 1 & -0.85 & Effect \\
\hline R8. & 5.85 & 6.77 & 12.62 & 6 & -0.93 & Effect \\
\hline R9. & 6.43 & 6.40 & 12.83 & 3 & 0.03 & Cause \\
\hline R10 & 6.70 & 6.03 & 12.73 & 4 & 0.67 & Cause \\
\hline
\end{tabular}

